\title{
Cashew Apple Juice Anacardium Occidentale L Probiotic Fermented from Lactobacillus acidophilus
}

\author{
By
}

Nguyen Thi Thuy Giang ${ }^{1}$, Nguyen Thu Kieu ${ }^{1}$, Tran Nhat Nam²,

\author{
Dong Thi Anh $\mathrm{Dao}^{2}$ and Nguyen Phuoc Minh${ }^{2}$
}

\begin{abstract}
The development of these probiotic beverages is important to diversify the market and to attend benefits to human health of large intestine. The aim of this study is using fruit juice from cashew apple as a substrate for the growth of Lactobacillus acidophilus. In order to create a new good probiotic beverages for human health and decrease environmental impurity from ripe cashew apples. The result shows that juice from ripe cashew apples after remove tannin and pasteurization at $90^{\circ} \mathrm{C}$ on 10 minutes and additional $11 \%(\mathrm{w} / \mathrm{v})$ sucrose can be suitable substance for growthing of Lactobacillus acidophilus. The optimum conditions of Lactobacillus acidophilus growth in cashew apple juice are: the initial $\mathrm{pH}$ 4.0-4.5, the temperature value $37^{\circ} \mathrm{C}$. Cell biomass of $\mathrm{L}$. acidophilus after being fermented at $37^{\circ} \mathrm{C} / 48$ hours is greater $10^{9} \mathrm{cfu} / \mathrm{mL}$.
\end{abstract}

Key words: cashew apple, fermentation, Lactobacillus acidophilus, probiotic.

\section{Introduction}

Cashew tree (Anacardium Occidentale $L$ ) is a perennial plant originated from Northeastern Brazil but now widely grown in India, Vietnam, Tanzania and Mozambique. Especially in Vietnam, it is mostly planted in the south such as Binh Duong - Binh Phuoc (82,000 ha), Dong Nai (35,000 ha), Ba Ria -Vung Tau (20,000 ha), Tay Ninh (10,000 ha), but not in the north.

Cashew apple fruit includes two parts: true and false fruit. The true fruit is surrounded by shell and nut, false fruit is developed from pedicel. False fruit contains $90 \%$ whole fruit weight. The pulp of the cashew apple is very juicy with $85-90 \%$ water; $7-13 \%$ carbohydrate; $0.7-0.9 \%$ protein; $0.2 \%$ mineral; 0.1 lipid; vitamin $\mathrm{C}$ at high content $(261.5 \mathrm{mg}$ per edible part), five or six fold compared to orange, eight fold compared to mandarin orange; other vitamin B1, B2 and mineral calcium, phosphorous and ferrous. However, pulp of the cashew apple is usually discarded during harvest, so wasteful and harmful to environment. 
There are many research concerned to benefit of probiotic to human health such as bacteria resistance, lactose metabolized improvement, cholesterol reduction, Helicobacter pylori immune [4]. Probiotic is supplemented into milk and fermented dairy products. However, demand of non-milk probiotic products is increasing so that consumption of fruit and vegetable can be seen as an substrate for growing and accumulating of probiotic bacteria owing to high content of mineral, vitamin, fiber and anti-oxidizer.

Ana Lúcia Fernandes Pereira et al. optimized the growing condition of $L$. casei in cashew apple extract, evaluated the living ratio of this bacteria after being preserved in $4^{0} \mathrm{C}$ within 42 days. [1]. Kyung Young Yoon et al. used potato extract as substrate for fermentation from $L$. acidopbilus $L A 9, L$. plantarum C3, L. casei A4 and L. delbrueckii D7. This extract was incubated with bacteria within 24 hours at $30^{\circ} \mathrm{C}$. Results were shown that lactic bacteria reduced $\mathrm{pH}$ to 4.1 and increased acidity to $0,65 \%$, biomass $1-$ $9 \times 10^{9} \mathrm{cfu} / \mathrm{mL}$ after 72 hours fermented. After 4 week preservation at $4^{\circ} \mathrm{C}$, living cells were in range $10^{6}-10^{8} \mathrm{cfu} / \mathrm{ml}[2]$.

Main purpose of this research surveys the growth of Lactobacillus acidophilus in cashew apple extract to diversify probiotic products in the market based on available by-product from cashew apple cultivation.

\section{Material and Method}

\subsection{Cashew apple extract}

Cashew apple fruits were collected in Dong Nai province, utilized the pulp of cashew apple to get the extract. Tannin was eliminated by heating at $55^{\circ} \mathrm{C}, 60^{\circ} \mathrm{C}, 65^{\circ} \mathrm{C}, 70^{\circ} \mathrm{C}$ within $3,5,7,9$ minutes then cooling at $5^{\circ} \mathrm{C}$ in $10,15,20,25$ minutes to condensed tannin. Filtrate was then heated at $90^{\circ} \mathrm{C}$ in 10 minutes.

\section{Recovery of tannin separation}

In there:

$$
H_{1}=\frac{a_{1}-a_{2}}{a_{1}} \times 100 \quad H_{2}=\frac{a_{2}-a_{3}}{a_{2}} \times 100
$$

$\mathrm{H}_{1}$ : recovery of tannin after being heated, $\%$.

$\mathrm{H}_{2}$ : recovery of tannin after being cooled, $\%$.

$a_{1}$ : content of tannin in raw extract, $g$.

a2: content of tannin after being heated, $g$.

$\mathrm{a}_{3}$ : content of tannin after being cooled, $\mathrm{g}$.

\subsection{Testing methods}

Using quantitative testing methods for chemical and physicochemical criteria: moisture content [TCVN 5613 - 91], total sugar [TCVN 4594 - 88], tannin [ISO 9648:1988], vitamin C [TCVN 4715 - 89]. polyphenol [Folin - Ciocalteau]. Experiments were conducted with three replications and then statistically summarized by StarGraphics 3.0 at reliability 0.05 . 


\subsection{Culture medium preparation}

Lactobacillus acidophilus was provided from biological laboratory of HCMC University of Technology. Inoculate this bacteria on agar medium and then accumulate level 1 and level 2. Biomass in MRS medium after 24 hours at $30^{\circ} \mathrm{C}$ attained at $7.86 \times 10^{\circ} \mathrm{cfu} / \mathrm{ml}$. Inoculate $1 \mathrm{ml}$ of MRS broth into Erlen containing $100 \mathrm{ml}$ cashew apple extract to monitor the growth curve. Biomass of cashew apple extract attained $10^{8} \mathrm{cfu} / \mathrm{ml}$ after $16-$ 18 hours at $30^{\circ} \mathrm{C}$. This bacteria in this culture was used to further fermentation.

\subsection{Fermentation condition}

Selected fermentation condition was based on growing characteristics of Lactobacillus acidophilus at four levels of temperature: $25,32,37$ and $42^{\circ} \mathrm{C} . \mathrm{pH}$ initial was adjusted from $3.5-5.5$ with difference 0.5 . Sugar supplemented into cashew apple extract $\%(\mathrm{w} / \mathrm{v}) 5,7$, $9,11,13,15 \%$. Fermentation was executed at $30^{\circ} \mathrm{C}$ in 48 hours with above parameters. Output criteria would be living cells, $\mathrm{pH}$, acid lactic, total sugar. Acid lactic content was defined [3]. Total acidity ( $\mathrm{g} / \mathrm{l})$ converted to acid lactic in fermented culture.

In there:

$$
\left(V-V_{0}\right) \times 0,1 \times \frac{90}{10}=(\mathrm{V}-\mathrm{Vo}) \times 0,9
$$

$\mathrm{V}$ : volume (ml) of $\mathrm{NaOH}$ used to neutralize $10 \mathrm{ml}$ of fermented sample.

$\mathrm{V}_{0}$ : volume (ml) of $\mathrm{NaOH}$ used to neutralize $10 \mathrm{ml}$ of blank sample.

\subsection{Determine living cells}

Living cells were determined by diluting with distill water to $10^{-6}$. Take $0.1 \mathrm{ml}$ of diluted solution and then spread on MRS agar dishes. After that these dishes were incubated at $37^{\circ} \mathrm{C}$ in 72 hours. Dishes having $25-250 \mathrm{cfu}$ would be selected to number. Numbers of bacteria were expressed by $\log \mathrm{cfu} / \mathrm{ml}$ [3].

\section{Counting method}

- $\quad$ Dilute sample to appropriate concentration.

- $\quad$ Take $0.1 \mathrm{ml}$ sample and spread on Petri dishes.

- $\quad$ Incubate $30^{\circ} \mathrm{C}$ in $24-48$ hours.

- Count colony present on agar dish.

- $\quad$ Number of bacteria in $1 \mathrm{ml}$ sample were calculated as formula:

$$
N=\frac{\sum \text { colonies }}{n_{1} \times v_{1} \times f_{1}+\ldots+n_{i} \times v_{i} \times f_{i}}
$$

In there:

$\mathrm{N}$ : number of Petri dishes at an appropriate diluted level. $\mathrm{v}$ : volume of sample inoculated.

f: ratio of dilute.

\section{Results \& Discussion}

\subsection{Tannin separation}

Fig. 1 and 2 expressed tannin separation recovery after being heated at different temperatures in various intervals. Increasing temperature to $55^{\circ} \mathrm{C}$, we got low reparation recovery and acrid product. Contrary, increasing temperature to $70^{\circ} \mathrm{C}$, we got high 
reparation recovery but low quality product, especially vitamin $\mathrm{C}$ reduction, non-specific nature of cashew and cook flavor. So this temperature was not selected. Meanwhile, heating at $60^{\circ} \mathrm{C}$ and $65^{\circ} \mathrm{C}$ the difference of tannin separation recovery at these experiments was not statistically significant $(\mathrm{P}<0.05)$ so temperature $60^{\circ} \mathrm{C}$ with tannin separation recovery 37.13 $\pm 1.6 \%$ was appropriate to select for further researches. There were statistically significant differences of tannin separation recovery at various intervals. However, at higher interval,

high tannin separation recovery but low quality product flavor. So, 5 minutes was very suitable to tannin denaturation and high quality product flavor. Fig. 3 showed the effect of cooling time to tannin separation recovery. There were statistically significant differences of cooling time intervals to tannin separation recovery. We got the highest tannin separation recovery at 20 minutes with $92.35 \%$ tannin separated and lowest at 10 minutes with $85.56 \%$. However between 20 minutes and 25 minutes there were not statistically significant differences so cooling time at 20 minutes in $5^{\circ} \mathrm{C}$ was very ideal for tannin precipitation.

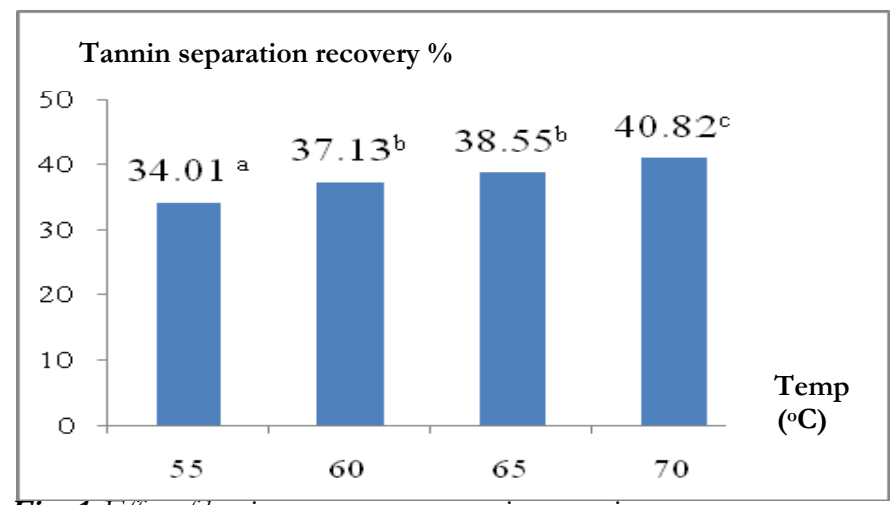

Fig. 1. Effect of heating temperature to tannin separation recovery

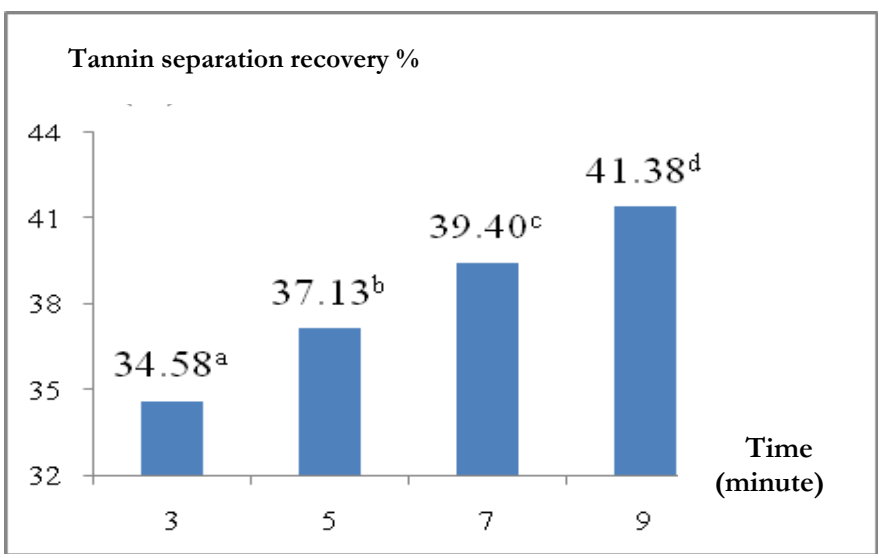

Fig. 2. Effect of heating time to tannin separation recovery 


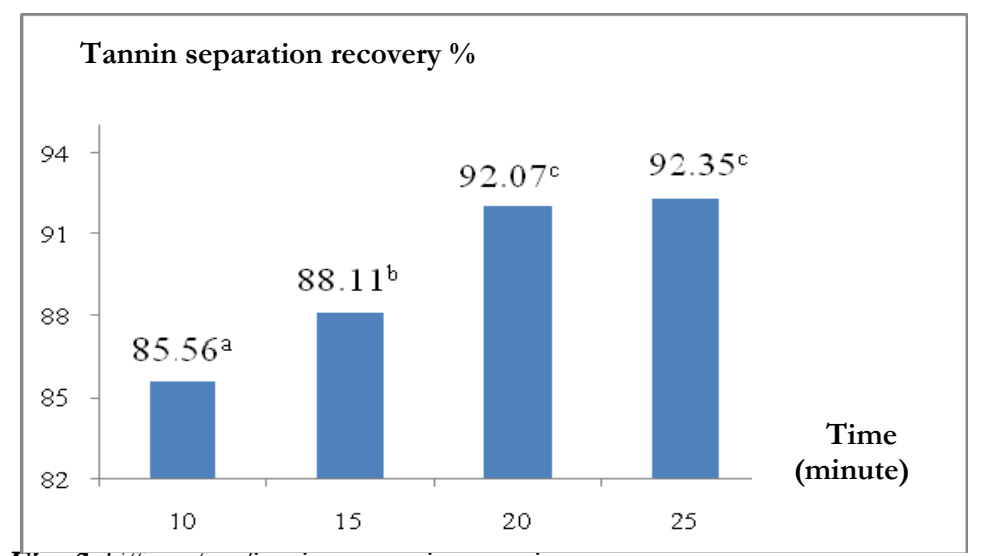

Fig. 3. Effect of cooling time to tannin separation recovery

\subsection{Temperature and time for pasteurization}

We conducted the research at three pasteurized intervals: 10 minutes, 15 minutes, 20 minutes and three pasteurized temperatures: $70^{\circ} \mathrm{C}, 80^{\circ} \mathrm{C}, 90^{\circ} \mathrm{C}$ with the aim to define the optimum temperature and time for pasteurization.

Table1. Temperature and time for pasteurization

\begin{tabular}{|c|c|c|c|}
\hline $\begin{array}{r}\text { Temperatu } \\
\text { re }\end{array}$ & \multicolumn{3}{|c|}{$\begin{array}{r}\text { Vitamin C content } \\
(\mathbf{m g} / \mathbf{L})\end{array}$} \\
\hline $\mathbf{1 0}$ minutes & 131 & 123 & 102 \\
\hline $\mathbf{1 5}$ minutes & 114 & 104 & 91 \\
\hline $\mathbf{2 0}$ minutes & 98 & 85 & 78 \\
\hline
\end{tabular}

Basing on vitamin C research, we can see temperature and interval increased, vitamin C decreased. At $70^{\circ} \mathrm{C}$ in 10 minutes, we got the highest $\mathrm{C}$ and gradually decreased at higher temperature. Sample would then be pasteured $70^{\circ} \mathrm{C}$ in 20 minutes, TPC got at $8,9 \times 10^{1} \mathrm{cfu} / \mathrm{ml}$, so we didn't choose $70^{\circ} \mathrm{C}$. Checking $80^{\circ} \mathrm{C}$ in 15 minutes, TPC showed at $3 \times 10^{\circ} \mathrm{cfu} / \mathrm{ml}$ so we also didn't choose $80^{\circ} \mathrm{C}$ and 10,15 minutes. At $80^{\circ} \mathrm{C}$ and 20 minutes, vitamin $\mathrm{C}$ content was very low so we didn't choose either. We selected $90^{\circ} \mathrm{C}$ to further experiments. 


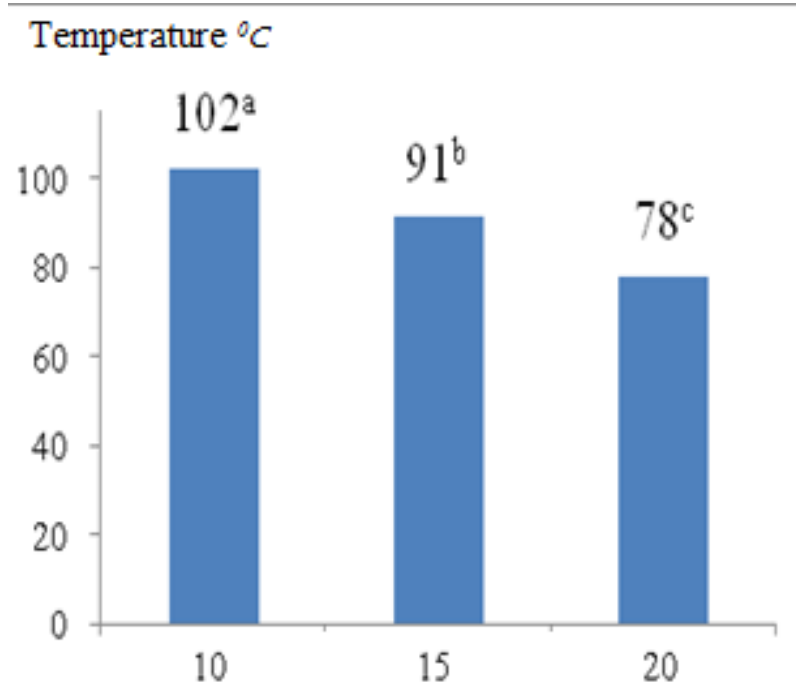

Fig. 4. Affect of pasteurization at $90^{\circ} \mathrm{C}$

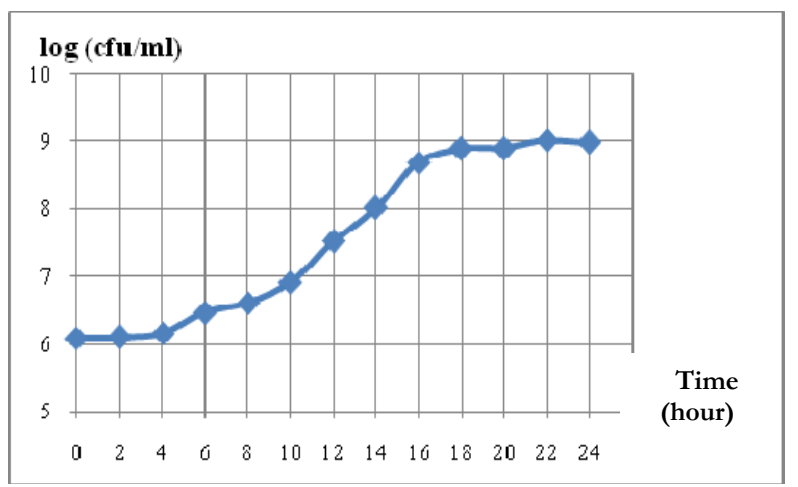

Fig. 5. Growth curve of Lactobacillus acidophilus in cashew extract culture

Cashew apple extract was pasteured at $90^{\circ} \mathrm{C}$ in 10 minutes and then cooled before adding bacteria $7,86 \times 10^{8} \mathrm{cfu} / \mathrm{ml}$. After that, we constantly monitored the growth curve during 24 hours. After 2 hours we took $0.1 \mathrm{ml}$ of culture medium spread on Petri dishes to count living bacteria. The growth curve could be seen in Fig. 5 .

\subsection{Fermentation condition}

In order to see clearly the fermentation, we built the growth curve of L. acidophilus in cashew apple extract. Fig. 5 obviously showed the high growth during $6-18$ hours. Saccharose supplementation would not only create substrate for bacteria but also enhance the sensory characteristics. However, if there was too much sugar, bacteria would be prohibited. In contrast, there was too little sugar, acid lactic formation would be 
low, sugar residue would also be scare and affected to product quality. Fig. 6 showed acid lactic content and Lactobacillus acidophilus increasing $5-11 \%$; the highest value at sugar concentration $11 \%$ with acid lactic $2,31 \mathrm{~g} / \mathrm{L}$ and bacteria $8.97 \mathrm{log} \mathrm{cfu} / \mathrm{ml}$ (There were statistically significant differences among experiments with liability $<0.05)$. However, when sugar concentration increased to $13-15 \%$, acid lactic content and bacteria also gradually decreased.

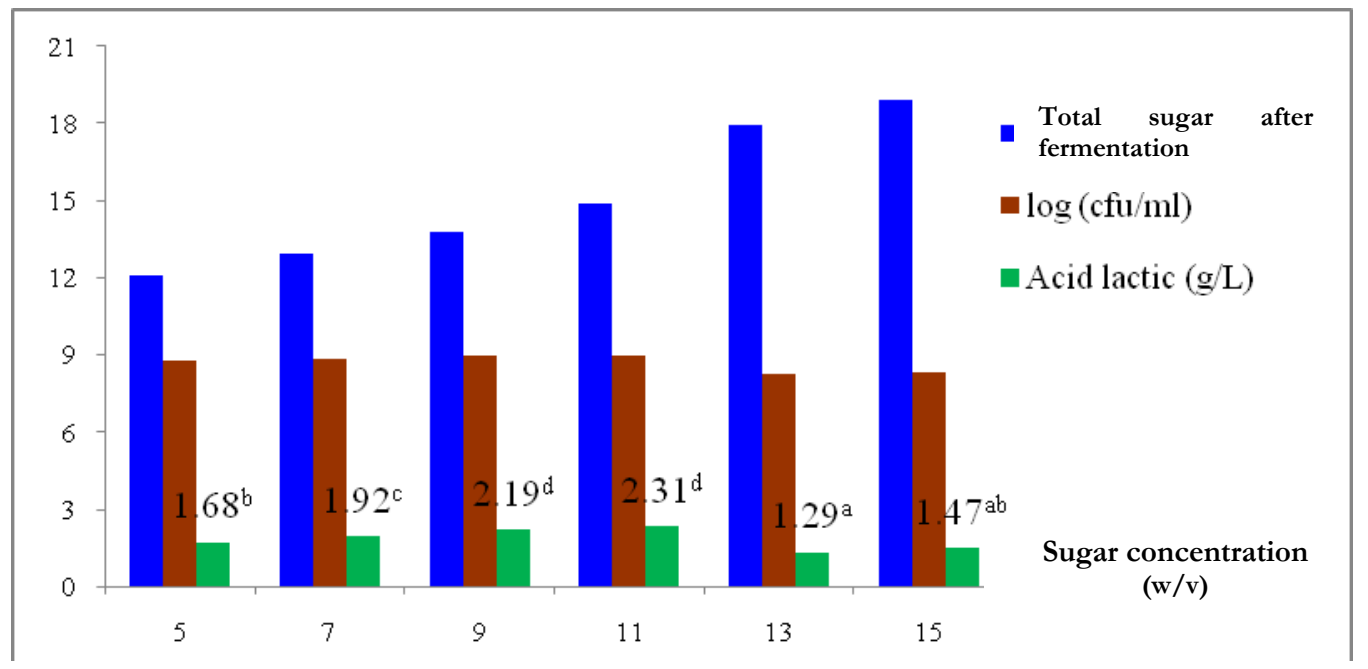

Fig. 6: Affect of sugar concentration to fermentation

$\mathrm{pH}$ initial and temperature had affected to the growth and stability of bacteria. Each species had an optimum temperature and $\mathrm{pH}$ appropriate for growing. Fig. 6 showed L. acidophilus well growing at $\mathrm{pH} 4.0-4.5$ with the highest colony $\left(8.95 \times 10^{8} \mathrm{cfu} / \mathrm{ml}\right.$ for $\mathrm{pH} 4$ and $9.47 \times 10^{8} \mathrm{cfu} / \mathrm{ml}$ for $\left.\mathrm{pH} 4.5\right)$. When $\mathrm{pH}$ over 5.0 and 3.5 colonies significantly downward $7.53 \times 10^{8} \mathrm{cfu} / \mathrm{ml}$ with $\mathrm{pH} 5.5$ and $6.9 \times 10^{8}$ with $\mathrm{pH} 3.5$. This was very important because bacteria used for probiotic must be endured acidity in stomach to survive and trap on small intestine. Content of acid lactic was also be affected by $\mathrm{pH}$ initial because optimum $\mathrm{pH}$ would create favorable condition for strong growth of bacteria so substrate could be powerfully metabolized. Content of acid lactic received highest at $\mathrm{pH} 4.5$ and lowest at $\mathrm{pH} 3.5(2.91 \mathrm{~g} / 1$ and $0.84 \mathrm{~g} / 1$ consequently). There were statistically significant differences among experiments with liability $<0.05$. This result could be compared to one of Ana Lúcia Fernandes Pereira et al. (2010) with the optimum fermentation condition: $\mathrm{pH}=6.4$; temperature $30^{\circ} \mathrm{C}$, living bacteria $7.48 \mathrm{log} \mathrm{cfu} / \mathrm{mL}$ after 16 hours. 


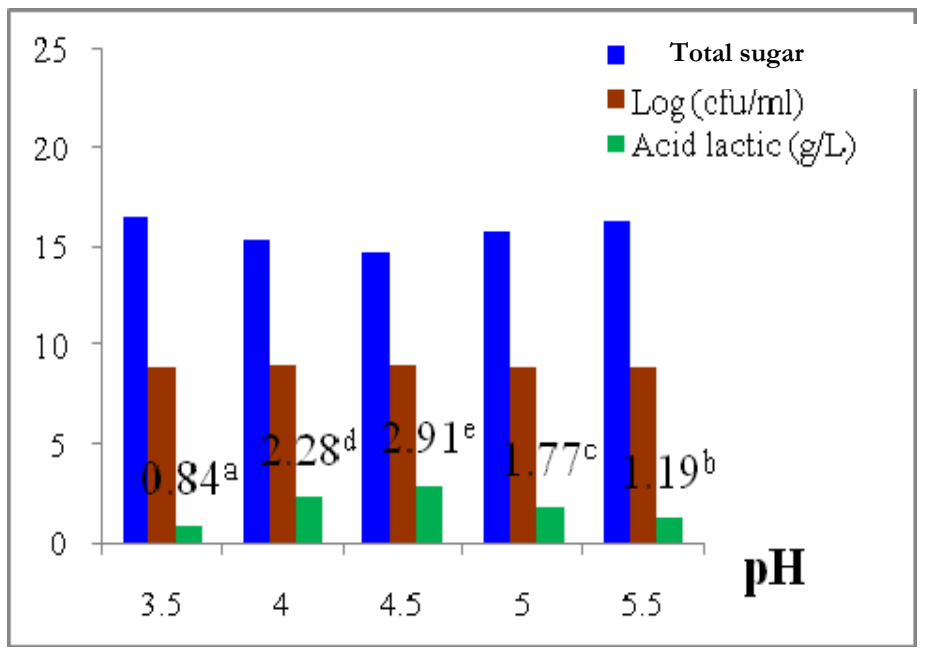

Fig. 7: Effect of $p H$ to fermentation.

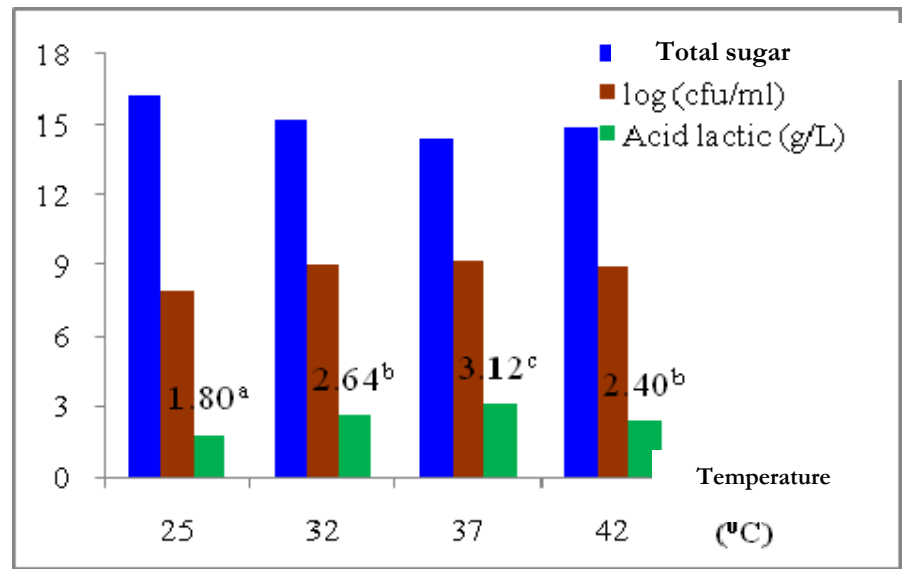

Fig. 8: Effect of temperature to fermentation

Compare to $\mathrm{pH}$, temperature obviously affected to Lactobacillus acidophilus growth. Fig. 8 showed that at $37^{\circ} \mathrm{C}$ bacteria accumulated after fermentation $1.57 \times 10^{\circ} \mathrm{cfu} / \mathrm{ml}$ with the highest content of acid lactic $3.12 \mathrm{~g} / 1$ and at $25^{\circ} \mathrm{C}$ bacteria was very weak in four temperature regimes $8.35 \times 10^{7} \mathrm{cfu} / \mathrm{ml}$ wth the highest content of acid lactic $1.8 \mathrm{~g} / \mathrm{l}$. There were statistically significant differences among experiments with liability $<0.05$. This result proved evidence that Lactobacillus acidophilus completely immobilized inside human body.

\section{Conclusion}

This research removed a large amount of tannin out of cashew apple juice with recovery $92.07 \%$. By heating at $60^{\circ} \mathrm{C}$ in 5 minutes and cooling $5^{\circ} \mathrm{C}$ in 20 minutes, cashew apple extract could be used as beverage and fermented with Lactobacillus acidophilus to create probiotic product. Biomass of $L$. acidophilus was in range $16-18$ hours. Other optimum 
parameters of fermentation process: saccharose $11 \%, \mathrm{pH} 4.0-4.5$, temperature $37^{\circ} \mathrm{C}$. Cashew apple juice could be evaluated as an appropriated substrate for Lactobacillus acidophilus fermentation. With vitamin $\mathrm{C}$ and mineral available inside juice, cashew apple juice fermented probiotic Lactobacillus acidophilus was highly value for human health.

\section{References}

[1] Ana Lucia F.Pereira. Probiotic beverage from cashew apple juice fermented with Lactobacillus casei, 2010

[2] Kyung Young Yoon. The Microbiological Society of Korea Probiotication of Tomato Juice by Lactic Acid Bacteria. The Journal of Microbiology, 42, p.315-318, 2004.

[3] Isabel Moreira da Silva, Maria Cristiane Rabelo, Sueli Rodrigues. Cashew juice containing prebiotic oligosaccharides. Association of Food Scientists \& Technologists, 2012.

[4] Ni Lay Demi 'R. The Effects of Different Initial Lactobacillus Plantarum Concentrations On Some Properties Of Fermented Carrot Juice. Ministry of Agriculture and Rural Affairs Ankara, Turkey, 2006.

[5] Lin Kiat Saw. Fermentation of Tropical Fruit Juices by Lactic Acid Bacteria, School of Chemical \& Life Sciences, Singapore Polytechnic, 500 Dover Road, Singapore 139651.

[6] Nguyễn Đức Lượng. Thi nghiệm công nghệ sinh học (tập 2). Thí nghiệm vi sinh vật, NXB ĐHQG Tp.HCM, 2004.

[7] Phạm Thị Nga. Nghiên cưu sản xuất sản phẩm probiotic nước cà rốt tù vi khuẩn L. Plantarum. ĐH Đà Nẵng, 2011.

[8] Lê Hà Vân Thư. Bước đầu nghiên cứu tạo sản phẩm đồ uống lên men lactic từ cơ chất gạo lức, 2008. 
